Prace Literackie LIX

Wrocław 2019

https://doi.org/10.19195/0079-4767.59.7

JANUSZ WALIGÓRA

ORCID: 0000-0001-7939-8936

Uniwersytet Pedagogiczny

im. Komisji Edukacji Narodowej w Krakowie

\title{
Autoportret z lisem. Przeszłość do przezwyciężenia w prozie autobiograficznej Magdaleny Tulli
}

\section{Wstęp}

Głównym przedmiotem analizy i refleksji w prezentowanym szkicu jest kreacja dziecięcego bohatera autobiograficznej prozy Magdaleny Tulli — Włoskich szpilek $^{1}$ oraz Szumu ${ }^{2}$. Referencjalność obu tekstów, uchwytna na różnych poziomach identyfikacji świata przedstawionego, oraz dominująca w nich (choć nie jedyna) strategia realistyczno-psychologiczna odróżniają te książki od wcześniejszych utworów autorki $S k a z y^{3}$, opisywanych przez krytykę w kategoriach ostentacyjnej kreacji i fikcji (także metafikcji), paraboliczności, gry zastanymi kodami, figurami i strukturami, (nad)reprezentacji bogatej symboliki i metaforyki ${ }^{4}$. Wspo-

${ }^{1}$ M. Tulli, Włoskie szpilki, Warszawa 2011. Dalej jako WS, w nawiasie skrót i numer strony.

${ }^{2}$ M. Tulli, Szum, Kraków 2014. Dalej jako Sz, w nawiasie skrót i numer strony.

3 Sny i kamienie (Warszawa 1995), W czerwieni (Warszawa 1998), Tyby (Warszawa 2003), Skaza (Warszawa 2006), Kontroler snów (pod pseudonimem Marek Nocny, Warszawa 2007).

${ }^{4}$ Należałoby przytoczyć wszystkie recenzje i artykuły odnoszące się do tej fazy twórczości Magdaleny Tulli. Podobny sposób interpretowania jej utworów (w mniejszym stopniu dotyczył on debiutanckich Snów i kamieni) dobrze oddają tytuły recenzji (oto kilka wyrazistych przykładów): D. Nowacki, W rekwizytorni, „Kresy” 1998, nr 36, s. 160-162; J. Orska, Grubymi nićmi szyte, „Arkusz” 1999, nr 3, s. 7; J. Gondowicz, Lust zu fabulieren, „Nowe Książki” 2003, nr 6, s. 59; M. Orski, W ,jałowych piaskach” historyjek, „Odra” 2003, nr 12, s. 101-102; M. Zaleski, Złowróżbna tatwość stwarzania świata, „Gazeta Wyborcza” 2006, nr 26, dodatek „Kultura”, s. 13. Sama autorka w rozmowie z Justyną Dąbrowską z jednej strony dystansuje się wobec czytania Włoskich szpilek jako autobiografii, wskazując na prawa i mechanizmy konstrukcji literackiej, z drugiej polemizuje z przypisywaniem jej wcześniejszym powieściom głównie walorów metafikcji (Jaka piękna iluzja. Magdalena Tulli w rozmowie z Justyną Dąbrowską, Kraków 2017, s. 95-98). Wskazuje w ten sposób na głębszą koherencję swych dawniejszych i nowszych tekstów, która stała się obecnie bardziej 
mnienia narratorki Włoskich szpilek oraz narratorki Szumu — oba głosy, mimo pewnych różnic, składają się w jedną całość, której podstawą jest nie tylko zaplecze autobiograficzne, wspólna tożsamość bohaterek i czasoprzestrzeń ${ }^{5}$, ale też podobieństwo tonu i stylu — koncentrują się na bolesnej rodzinnej przeszłości, która stanowi dla wspominającej niełatwe do przezwyciężenia wyzwanie. W przeciwieństwie do zrozumiałej psychologicznie i utrwalonej w kulturze oraz praktyce społecznej idealizacji dzieciństwa książki Tulli oferują czytelnikowi swoistą wyprawę do ,jądra ciemności" ${ }^{\prime}$ — obraz opresji, emocjonalnej destrukcji i unieszczęśliwienia, obraz świata, w którym „rodzina staje się źródłem cierpień”7.

\section{Poruszenie bólu}

Potrzebę ekspresji traumatycznego doświadczenia wzmacnia wyraźna deklaracja narratorki, która mówi o konieczności uporania się z przemilczaną, nieprzepracowaną przeszłością. Obrazy bólu, ujmowane pod postacią skondensowanych scen i wyimaginowanych fotografii, są jak wrażliwa rana, niosą potencjalność autodestrukcji. Pobudzanie ich do życia impulsem wspomnienia jest ryzykowne, ale otwiera możliwość adaptacji cierpienia, przepracowania urazów przeszłości ${ }^{8}$. Podlega przy tym logice tekstu literackiego, który zmierza ku jakiemuś domknięciu, podsumowaniu. Oba te połączone z sobą aspekty ujawnia komentarz do wymyślonej szkolnej fotografii (o której będzie jeszcze mowa):

uchwytna („Klucz był tak dobry, że pasował też do wcześniejszych książek, co jakimś cudem zostało od razu dostrzeżone”, ibidem, s. 96) i która zasadza się głównie na doświadczeniu opresji: „To były nasze wspólne doświadczenia: żyliśmy w opresji, doznając tych samych upokorzeń, przed którymi nie było jak się bronić. Decydowano za nas, jakbyśmy nic nie znaczyli, poniżano nas w szkole, w wojsku, w pracy i na porodówce, takie były zwyczaje" (ibidem, s. 97).

${ }^{5}$ M. Rusek, Niewyshuchany krzyk, [w:] Światy dzieciństwa. Infantylizacje w literaturze i kulturze, red. M. Chrobak, K. Wądolny-Tatar, Kraków 2016, s. 343. Dariusz Nowacki określa Szum jako „wariant” (czyli „to samo w innym ujęciu i opracowaniu”) Włoskich szpilek; idem, „Szum” Magdaleny Tulli. Powieść nie do przecenienia, „Gazeta Wyborcza” 30.09.2014, http://wyborcza. pl/1,75410,16725324,_Szum_Magdaleny_Tulli_Powiesc_nie_do_przecenienia_html [dostęp: 28.03.2018]. Tadeusz Sobolewski z kolei stwierdza, że Szum został jednak pomyślany szerzej uniwersalistycznie; idem, Nie ma zmyślonych opowieści, „Gazeta Wyborcza” 15-16.09.2012, s. 12, http://wyborcza.pl/1,75410,12487543,Nike_2012_Magdalena_Tulli_Nie_ma_zmyslonych_opowiesci.html [dostęp: 11.12.2017]. Magda Heydel przeciwstawia obraz samotnej bohaterki Włoskich szpilek obrazowi trudnych relacji dziewczynki z innymi ludźmi w Szumie; eadem, Byliśmy nieprzyjaciótmi, „dwutygodnik.com” 2014, nr 143, http://www.dwutygodnik.com/artykul/5479-bylismy-nieprzyjaciolmi.html [dostęp: 23.01.2017].

6 E. Rąbkowska, Potrzeba początku: kategoria dzieciństwa w polskiej wspótczesnej prozie wspomnieniowej, Warszawa 2015, s. 23.

${ }^{7}$ B. Darska, Wina i przebaczenie, „Nowa Dekada” 19.12.2014, http://nowadekada-online. pl/recenzuje-bernadetta-darska-z-magdalena-tulli-rozmawia-sabina-misiarz-filipek/ [dostęp: 19.10.2017].

${ }^{8}$ D. Nowacki, Wyzwolenie, ukojenie, „Tygodnik Powszechny” 2012, nr 43, dodatek „Angelus", s. 46. 
Obawiam się, że ta scena musi trwać, dopóki ból pozostanie ukryty poza kadrem, martwy, stężały, odcięty od niej, ode mnie i od świata. Jeśli ból się nie poruszy, nie dobrniemy do puenty. Lecz gdyby nagle ożył, czy nie zabije nas obu na miejscu jak grom z jasnego nieba? (WS, 101-102)

W tym sensie proces wspominania, któremu nadaje się literacki kształt, owo „poruszenie bólu” jest formą konfrontacji z przeszłością. Prowadzi ona — przez rozpoznanie i powtórzenie ${ }^{9}$ - do ujawnienia skrywanych urazów i uwolnienia thumionych emocji.

Jeśli chodzi o fenomen cierpienia, trochę inaczej mówi o nim narratorka, a trochę inaczej autorka omawianej prozy. We Włoskich szpilkach mowa o bólu ukrytym i stężałym, zachowanym w stanie nienaruszonym, z kolei w rozmowie z Justyną Dąbrowską Tulli opisuje rozciągający się w czasie proces „rozpuszczania się” bólu: „Ból musi się rozpuścić, rozpuszcza się długo. Emocje osiadają, umysł zaczyna je oglądać. To trwa" ${ }^{10}$. W tym ujęciu pisanie jako finalny efekt długiego mierzenia się z psychicznymi urazami nie zyskuje statusu wyzwalającej autoterapii („Gdybym chciała się leczyć pisaniem, nie dałoby się tego czytać”" ${ }^{11}$. Jednak nadal pozostaje formą obcowania i radzenia sobie z własnym cierpieniem („Wspomnienie tamtej samotności jeszcze teraz mnie przytłacza”"12), ekspresją bólu oraz próbą pochwycenia własnego życia w spójną, przetworzoną literacko narrację. W tym sensie ,ja" pisarskie, jak pisze Ewa Wiegandt, dominuje we Włoskich szpilkach nad ,ja” autobiograficznym, co oznacza, że o bohaterce wspomnień opowiada się ,wypracowanymi środkami pisarskimi, by z dystansem narracyjnym zyskać dystans poznawczy, interpretacyjny do własnej osoby, spojrzeć na siebie oczami innych i dowiedzieć się, dlaczego jest właśnie taka, jaka jest"13. Praca nad literacką reprezentacją czasu minionego nosi mimo wszystko znamiona przepracowania ${ }^{14}$, zwłaszcza jeśli odnosimy jego oddziaływanie wobec figury ,ja" narracyjnego, które zmaga się z urazami dalszej i bliższej przeszłości, próbując złagodzić skutki traumy ${ }^{15}$.

Nie jest przy tym obojętny fakt artystycznych kompetencji autorki, umiejętność wysłowienia wewnętrznych odczuć i przeżyć w języku symbolicznym, transpozycji pracy pamięci w sugestywne obrazy i zwarte figury mowy. Retoryczna i kompozycyjna organizacja wspomnień wznosi je na poziom wysokoartystycznej prozy literackiej, której literackość zdaje się nad wyraz funkcjonalna i przekonująca.

${ }^{9}$ Zob. Z. Freud, Przypominanie, powtarzanie i przepracowanie, przeł. A. Czownicka, [w:] K. Pospiszyl, Zygmunt Freud: człowiek i dzieło, przeł. B. Kocowska et al., Wrocław 1991, s. 266272.

10 Jaka piękna iluzja, s. 49.

11 Ibidem.

12 Ibidem.

13 E. Wiegandt, „To” Magdaleny Tulli, „Poznańskie Studia Polonistyczne. Seria Literacka” 2013, nr 22 (42), s. 144.

14 Z. Freud, op. cit., s. 272.

15 D. LaCapra, Historia w okresie przejściowym, przeł. K. Bojarska, Kraków 2009, s. 154-155. 
Opowieść, której przedmiotem jest nieszczęśliwe dzieciństwo, przenikają uczucia smutku i melancholii ${ }^{16}$. Narratorka jest świadoma wszystkich komplikacji, w jakie uwikłane zostało jej dorastanie. Jest świadoma, że nie da się już odwrócić wyrządzonego zła, jak też że, być może, nie dałoby się mu zapobiec w przeszłości. Nie szuka wśród najbliższych tylko winy, choć ta wina jest bezsprzeczna. Użycza bezbronnej ofierze, czyli sobie sprzed lat, miłości i daremnego, bo spóźnionego wsparcia. Tęskni za tym, czego zaznawały inne dzieci i czego ona sama nigdy nie zaznała. Rozbiera swoją samotność na czynniki pierwsze i poddaje wiwisekcji z precyzją i wyczuciem doktora Tulpa, który w wierszu Grochowiaka inspirowanym słynnym obrazem Rembrandta bada wypełnioną cierpieniem kondycję ludzką. Zagłębia się w minionym czasie, utrwalając dramatyczne chwile, ale też spogląda na wszystko z dystansu, dojrzalsza i mądrzejsza o wiedzę, którą przyniósł bieg życia. Czas i dystans pomagają w podjęciu wysiłku zrozumienia i... wybaczenia.

\section{Niekochana}

Podstawowym źródłem cierpień, jakich doświadcza dziewczynka, przynajmniej $\mathrm{w}$ interpretacji narratorki, jest odmowa miłości ze strony matki:

Nie życzyła sobie być dotykana: dzieci zawsze mają lepkie ręce. Nie życzyła sobie kłopotów. A ja byłam fabryką kłopotów. Nie życzyła sobie mojego towarzystwa. Ani mojej miłości. (WS, 32)

Nie chodzi więc o doraźne zaniedbania, błędy wychowawcze, akty niechęci czy agresji, bo i takie sie pojawiają, ale o istotę stosunku matki do córki. Zaburzenia zdawałoby się tych najbardziej oczywistych relacji wyrażają się chłodem matki, która nigdy nie przytula swego dziecka, zniecierpliwieniem i znużeniem szkolnymi kłopotami dziewczynki, niedbaniem o jej emocjonalne potrzeby, w tym poczucie bezpieczeństwa i wsparcia.

Po latach dochodzi bolesna wiedza o faktach, które miały miejsce tuż po narodzeniu dziecka: po kilku tygodniach niemowlę zostało wysłane do Mediolanu, do włoskiej rodziny ojca. Mimo dobrej i czułej opieki tęskniło za matką, o czym Tulli pisze z właściwą sobie gorzką ironią: „Widocznie dziecko nie potrafiło tego docenić, bo wrzaski, jak mówiono, nie ustawały dniem i nocą" (WS, 31). Z tego okresu pochodzą też mgliste wspomnienia kogoś, kto zastępował matkę dziewczynki. Jednak kruchość dziecięcej pamięci nie pozwoliła zatrzymać obrazu tej arcyważnej figury. Nieskuteczny wysiłek wywoływania jej z przeszłości przynosi rozczarowanie, kolejne źródło melancholii:

Wspomnienie najważniejszej w moim życiu osoby, mętne jak źle wywołana fotografia, wypływało czasem na moment i od razu znikało. Chciałam je zatrzymać, ale nie mogłam. Musiał to być

${ }^{16}$ K. Dzika-Jurek, Problem ciężaru. Melancholia w twórczości Magdaleny Tulli, Katowice 2014, http://www.sbc.org.pl/Content/139135/doktorat3519.pdf [dostęp: 21.03.2018]. 
ktoś, kogo znałam bardzo dobrze, zanim poznałam ją, moją matkę. Ktoś, kogo kochałam, i kto nie odepchnął mojej miłości. Niewyraźna postać pojawiała się jeszcze, ale tylko w snach, coraz rzadziej, jak za mgłą. To była mgła niepamięci. A wysiłek pamięci okazywał się daremny, przynosił tylko tęsknotę i rozpacz. (WS, 32-33)

\section{Szkolna fotografia}

Równie posępne i raniące są wspomnienia wczesnych lat szkolnych. I także w tym wypadku wykorzystuje Tulli figurę fotografii jako formę przedstawienia w syntetycznym, obrazowym skrócie opresywnej przeszłości. Żeby jednak odczuć w pełni wymowę tego obrazu, warto przywołać spektrum wykluczeń i upokorzeń, któremu dziewczynka podlega w szkole. Zaniedbana przez rodziców, często spóźnia się na lekcje. Pogardliwą uwagę zwraca jej wygląd — mundurek szkolny noszący ślady zupy ze stołówki i buzia poplamiona atramentem. Dwujęzyczna uczennica (matka — polska Żydówka, ojciec - Włoch) ma kłopoty z czytaniem i pisaniem. Jej zeszyty, pełne dziur i kleksów, są kompromitującym świadectwem jej niezdarności. Postrzegana jako osoba dziwaczna i opóźniona, bywa bita zeszytem po głowie i zamykana w szkolnej szafie. Zyskuje status klasowej ofermy, staje się uosobieniem nieporadności i nieszczęścia, czasem też bezbronnym kozłem ofiarnym. Kiedy w klasie giną pieniądze, dziewczynka jest główną podejrzaną i to jej matkę wzywa dyrektor do szkoły.

Małgosia (lub Karolina, ponieważ narratorka używa zamiennie obojga tych imion w odniesieniu do bohaterki wspomnień) jest wykluczona ze szkolnych kręgów towarzyskich, nie ma koleżanek, a tym bardziej przyjaciółek. Jedyną osobą, która łaskawie godzi się na jej towarzystwo, jest dziewczynka pochodząca ze Śląska, podlegająca podobnemu ostracyzmowi z racji niemieckiego brzmienia nazwiska matki i niechlubnej przeszłości wujków służących w czasie wojny w Wehrmachcie. Jednak i ona miewa swoje humory i bez skrupułów odpycha bohaterkę, gdy jest w gorszym nastroju. Narratorka odkrywa w ten sposób następną smutną regułę rządzącą międzyludzkimi relacjami i opisuje ją w charakterystyczny dla siebie żywy, plastyczny sposób:

Przywykłam do tego, że każdy, kto może sobie na to pozwolić, oddaje swój zły humor komu innemu, jak gorący kartofel, a następny robi to samo i chowa do kieszeni poparzone ręce. Dopiero ostatni z ostatnich, ten, kto nie miał na podorędziu już nikogo gorszego od siebie, nikogo, komu by mógł wepchnąć ten gorący kartofel do rąk, krótko mówiąc, ktoś taki jak ja — musiał go, parząc sobie usta i gardło, przełknąć. (Sz, 94-95)

Bohaterka jest w obrębie swojej szkolnej klasy, choć nie tylko tam, ostatnim ogniwem łańcucha dominacji i upokorzeń. Pochylając się po latach nad jej smutnym położeniem, świadomością odtrącenia i bólem osamotnienia, komponuje Tulli wymyśloną fotografię, która w skrócony, symboliczny sposób zatrzymuje i na wieki utrwala dramat dziewczynki. Zdjęcie ilustruje społeczny, anonimowy 
wyrok wydany na szkolnego „odmieńca”, małą istotę rozpaczliwie szukającą zrozumienia i akceptacji:

Gdyby istniało zdjęcie z tamtych czasów, ona byłaby na nim sama. Wychodziłaby zza krawędzi kadru z lewej strony, kierując się przed siebie, w stronę grupki dziewcząt odwróconych do niej plecami. Jedna czy druga uchwycona jeszcze w półobrocie, ale większość już się oddala, wydłużając krok, któraś z nich zdążyła zniknąć za prawą krawędzią, widać tylko obcas bucika zawieszony nad trotuarem. (WS, 101)

Wizualna figura odtrącenia i samotności sięga do rdzenia egzystencjalnej sytuacji małej bohaterki. Autoanaliza przyjmuje postać ekfrazy fikcyjnej fotografii, właściwie „stop-klatki”, która unieruchamia udrękę i reprodukuje w nieskończoność coś - parafrazując Barthes’a - co w rzeczywistości zdarzyło się wiele razy na wiele sposobów ${ }^{17}$. Podstawową właściwość fotografii, referencjalność, Tulli przekształca w kreację służącą wydestylowaniu metonimicznego obrazu samotności i upokorzenia.

Ta literacka stop-klatka zachowuje na zawsze przesyconą bólem przeszłość, na wzór straumatyzowanej pamięci, choć wydaje się tylko migawką i skrótem minionego. Tulli zręcznie operuje tu kompozycją, detalem oraz relacjami części do całości ${ }^{18}$, krojąc postacie brzegami kadru: bohaterka wyłania się z jednej krawędzi (z lewej strony), zapewne widoczna tylko częściowo, koleżanki znikają przecięte drugą (prawą). Jednej z nich brzeg fotografii odcina całe ciało, zostawiając tylko „obcas bucika”. Prawdziwym bohaterem sceny wydaje się to, co rozgrywa się między postaciami, czyli metaforyczna pustka, kiedy prośba o przyjaźń lub choćby możliwość funkcjonowania na koleżeńskich prawach w szkolnej wspólnocie spotyka się ze stanowczym odrzuceniem, odmową relacji.

Wyłania się jeszcze jeden bohater sceny — „prawdziwy ból”, który został „wypchnięty poza kadr”. Ten element, zachowany w czasie, przeniesiony na drugi brzeg życia (w świadomą dorosłość), łączy obie perspektywy czasowe: moment opowiadania i moment opowiadany, spaja podmiot dojrzały z dziecięcym. Ból konstytuuje wspólne ,ja”. Obudzenie i uwolnienie bólu — przez akt reprezentacji traumatycznego doświadczenia — jest propozycją i realizacją terapii ${ }^{19}$. Niesie szansę rozwiązania, przepracowania i jednocześnie ryzyko porażenia swą destrukcyjną mocą.

${ }^{17}$ R. Barthes, La chambre claire. Note sur la photographie, Paris 1980, s. 15-17, cyt. za: M. Zaleski, Formy pamięci, Gdańsk 2004, s. 41.

18 Por. M. Zaleski, Formy pamięci..., s. 48.

${ }^{19}$ Konfrontacja z bólem, rozgrywana przez Tulli na terytorium pamięci i słowa (sztuki), nie wydaje się w tym kontekście aktem „osłaniania” (M. Cuber, Metonimie Zagłady. O polskiej prozie lat 1987-2012, Katowice 2013, s. 15), ale odważną konfrontacją, do której trzeba było długo dojrzewać. Osłaniające aspekty można by prędzej dostrzec we wcześniejszej, maskującej fazie jej twórczości. 


\section{Lis}

Ponieważ trudno żyć w pustce, na marginesie wspólnoty (szkolnej czy rodzinnej), dziewczynka kreuje alternatywny świat wraz z oryginalnym przyjacie$1 \mathrm{em}^{20}$. Jest nim lis, który pochodzi z ulubionej włoskiej książeczki do kolorowania A mio primo Pallazi. Dla omawianych tekstów, zwłaszcza Szumu, to postać kluczowa, nie tylko dlatego że Tulli kontynuuje i rozwija w tej powieści koncept „nas lisów” zamykający Wtoskie szpilki, lecz także dlatego, że lis wyrasta tu na postać niemal pierwszoplanową, najbliższą emocjonalnie i towarzysko bohaterce. Bez lisa - wyznaje Tulli — być może w ogóle nie byłoby tej opowieści ${ }^{21}$.

Początek przyjaźni z lisem zostaje opisany w charakterystyczny sposób dla autobiograficznej prozy Tulli — przez mieszanie narracji pierwszoosobowej $z$ trzecioosobową i przesunięcie realistycznej, sprawozdawczej opowieści w sferę baśniowej kreacji:

Dziewczynka, która połamało krzesło, wyprowadziła się do lasu. Zamieszkała w przestronnej, wygodnej norze, pewnie po niedźwiedziu, i spała w niej na posłaniu z suchych liści. Nie wzięła ze sobą zeszytów ani budzika. Żywiła się orzeszkami laskowymi, jak wiewiórka. [...] Dziewczynka wędrowała leśną ścieżką, ubrana w moją zieloną sukienkę. Na innym obrazku siedział lis. Miał wesołe oczy i wzbudził we mnie zaufanie. (Sz, 50-51)

Pierwszoosobowa narratorka zamienia się w kreatorkę eskapistycznej opowieści o wyprowadzce do lasu i spotkaniu z lisem. Opowiada i rysuje obie postaci na kartonie z bloku, przypisując dziewczynce własne cechy (zniszczenie krzesła, zielona sukienka). Wykorzystanie zjawiska kompensacji i autoidentyfikacji w swobodnej narracji wywołującej efekt nakładania się realnego z wyobrażonym wskazuje na dobrą znajomość dziecięcej psychiki i sygnalizuje twórczy, kreacyjny charakter tekstu.

Ożywiony i spersonifikowany lis, pisany małą literą i pozbawiony imienia, jest z jednej strony przeciwieństwem bohaterki, reprezentuje bowiem cechy, których dziewczynce brakuje, i w ten sposób dopełnia jej postać. $Z$ drugiej — sporo go z nią łączy, dzięki czemu dobrze się rozumieją. „To część mnie — wyznaje autorka w rozmowie z Dorotą Wodecką — do celów literackich ozdobiona rudą kitą i właściwościami, które chciałabym mieć na stałe, a miewam tylko czasem" 22 . Zgodnie z zasadą różnicy można więc podkreślić atrybuty lisa, na których zbywa dziewczynce: jest egzotyczny, piękny, wyjątkowy, dziki, drapieżny, zaradny,

${ }^{20}$ S. Łupak, Dziewczynka, esesman i lis. Nowa ksiażka Magdaleny Tulli, „Newsweek” 13.10.2014, http://www.newsweek.pl/kultura/szum-nowa-powiesc-magdaleny-tulii-newsweek-pl,artykuly,348135,1.html [dostęp: 12.02.2018].

${ }^{21}$ W utartych torach nie miałam szczęścia się znaleźć, z Magdaleną Tulli rozmawia Sabina Misiarz-Filipek, „Nowa Dekada” 19.12.2014, http://nowadekada-online.pl/recenzuje-bernadetta-darska-z-magdalena-tulli-rozmawia-sabina-misiarz-filipek/ [dostęp: 19.10.2017].

22 Zbuntowana, z Magdaleną Tulli rozmawia Dorota Wodecka, „Gazeta Wyborcza” 2014, nr 225, s. 12 14, http://wyborcza.pl/magazyn/1,124059,16711994,Zbuntowana__rozmowa_z_ Magdalena_Tulli.html [dostęp: 14.09.2017]. 
przebiegły, mądry, doświadczony, dojrzały... Uwzględniając zasadę podobieństwa, warto z kolei zaznaczyć, że lis, tak jak bohaterka wspomnień, jest też osobnikiem z marginesu, wykluczonym, nielubianym, prześladowanym, samotnym.

Tulli bardzo akcentuje sekretność i wyłączność przyjaźni z lisem. Czuje się dzięki niej wyróżniona, niezwykła. Zdrada, której dopuszcza się wobec bohaterki koleżanka, rozpowiadając o tej tajemnicy innym uczennicom, naraża dziewczynkę na szyderstwo i kpiny. Ośmieszenie i uznanie bohaterki za cudaka mylącego realność z fantazją jest kolejnym ciosem godzącym w poczucie własnej wartości.

Inspiracją do rozwinięcia tego wątku mogło być opowiadanie Jerzego Andrzejewskiego Zloty lis. Zestawienie prozy Tulli z tekstem Andrzejewskiego ukazuje interesujące zależności i rozbieżności. Złoty lis pochodzi z roku 1954 i ukazał się w tomie pod tym samym tytułem, wydanym w roku 1955. Utwór - obok innych tekstów tam zamieszczonych, zwłaszcza Wielkiego lamentu papierowej głowy — można odbierać jako krytyczne przewartościowanie idei socjalizmu, socrealizmu oraz stalinowskiego systemu.

Lis pojawia się nagle bohaterowi, którym jest pięcioletni Łukasz. Zwierzę wyróżnia się niezwykłą urodą:

Był to przede wszystkim lis bardzo duży, lecz smukły i gibki, wspaniale rozrośnięty, o ślepiach połyskujących w ciemnościach, jak dwa rozżarzone węgielki, z wielką puszystą kitą, i co najbardziej zdumiewające: cały był złoty jakąś niezwykłą złocistością, miękką i jedwabistą, lśniąc w mroku zadziwiającym poblaskiem ${ }^{23}$.

Lis pozostaje tajemniczy i milczący. Prawie się nie odzywa, oprócz monosylabicznych chrząknięć w rodzaju „pa, pa!” czy „nigdy”. Jako miejsce pobytu wybiera szafę w dziecięcym pokoju. Nikt prócz Łukasza nie dostrzega niezwykłego gościa, co staje się źródłem udręki małego bohatera, potęguje wrażenie jego samotności i odrębności oraz przysparza mu rozmaitych kłopotów, gdy chłopiec chce się dzielić swoją radosną tajemnicą z innymi.

Lis w opowiadaniu Andrzejewskiego jest metaforą pewnej nadwyżki duchowej i osobowej. Symboliczne znaczenie pięknego gościa uwypukla się w dialogu rodziców, głównie przez sygnalizowane tam opozycje między tym, co prywatne (indywidualne) i piękne, a tym, co kolektywne (społeczne) i użyteczne. Bycie indywidualnością, prawo do fantazji, odróżnianie się od innych - to wartości kwestionowane w zideologizowanej krainie socjalizmu i gospodarki planowej. Nieprzydatność lisa dobrze ukazują dziecięce zabawy, w których powielane są ideologiczne klisze i propagandowe slogany (wyzysk psa Burka przez kapitalistów, zakładanie wsi spółdzielczej, akcja żniwna czy demaskowanie kułaka). W takiej skrajnie „uspołecznionej” rzeczywistości nie ma miejsca na „bezużytecznego" lisa, na piękno i tajemnicę. Łukasz, konsekwentnie formowany, by nie rzec współcześnie „formatowany” przez otoczenie (mówiąc wprost: poddany ideologicznemu ,praniu mózgu”), traci kontakt ze złotym gościem, który nagle

23 J. Andrzejewski, Zloty lis, [w:] idem, ,, Niby gaj” “ inne opowiadania, Warszawa 1967, s. 234. 
opuszcza jego mieszkanie. Początkowe wrażenie jest przygnębiające. Zniknięcie lisa przypomina utratę wiary, śmierć Boga, zagładę sensu, co dobitnie ukazuje wykorzystywane przez narratora słownictwo: Łukasza ogarniają ,pomroka” i „mrok”, dokoła panuje „martwa i głucha ciemność”, w której „brak życia”, w krąg rozciąga się ,pustka”.

Jednak chłopiec, uwiedziony zabawą w socjalistyczne przedsięwzięcia, o których wcześniej była mowa, dość szybko godzi się z utratą dziecięcej wiary, fantazji i tajemnicy. Na pytanie Krzysztofa, czy widuje jeszcze złotego lisa, odpowiada: „Pewnie, że nie widuję [...]. Przecież nie ma żadnych złotych lisów”24.

U Andrzejewskiego pojawienie się lisa wzmaga (przejściowo) indywidualizm chłopca i skazuje go na krótkie osamotnienie. U Tulli inaczej — lis pojawia się, ponieważ dziewczynka różni się od swoich rówieśniczek i czuje samotna. Zwierzę wypełnia towarzyską i emocjonalną pustkę, a jednocześnie jest najlepszą wersją marzenia o przyjaźni, jaka przychodzi bohaterce do głowy.

Tulli, sięgając po postać utrwaloną w tradycji bajki zwierzęcej, bohatera utworów Ezopa, Jeana de La Fontaine'a, Ignacego Krasickiego, Adama Mickiewicza, Jana Lemańskiego czy Jana Brzechwy, przełamuje alegoryczny wizerunek lisa, czyni z niego istotę zdecydowanie bardziej złożoną, niemal wielowymiaro$w_{a ̨}{ }^{25}$. Zgodnie $\mathrm{z}$ regułami antropomorfizacji lis $\mathrm{w}$ powieściach Tulli zachowuje się jak człowiek. Rozmawia z dziewczynką i stara się ją wspierać. Nowy przyjaciel staje się czymś więcej niż wcieleniem sprytu czy podstępności, bywa przewodnikiem i mędrcem, który dzieli się z dziewczynką swym życiowym doświadczeniem. I tak jak w Małym Księciu Saint-Exupery’ego lis dawał chłopcu lekcję przyjaźni, tak w Szumie uczy dziewczynkę, jak przetrwać. Udziela jej przy tym wielu bezcennych rad: żeby nie brała zbyt wiele na swoje barki, żeby nie walczyła i nie gryzła, kiedy sprawa jest przegrana, żeby się nie tłumaczyła, kiedy zarzuty są niesprawiedliwe i absurdalne, żeby umiała zachować spokój w najtrudniejszych chwilach:

Kiedy milczysz, muszą sami coś mówić, muszą machać rękami i krzyczeć, a my nic. Odpoczywamy i czekamy, aż się zmęczą. $(\mathrm{Sz}, 56)$

Strategia dystansu i biernego oporu ma wszakże swoje granice ${ }^{26}$. Wyznacza je poczucie upokorzenia: „Żadne zwierzę nie jest stworzone do znoszenia upokorzeń" $(\mathrm{Sz}, 79)$. Tu lis przemawia jednak bardziej jak opiekun i terapeuta niż leśny mistrz przetrwania.

${ }^{24}$ Ibidem, s. 286.

${ }^{25}$ Dlatego baśniowość lisa, o której pisze Ewelina Rąbkowska, wydaje się nieco problematyczna. Nie do końca też przekonuje opis mechanizmu terapii w rozumieniu wspomnianej badaczki: „Lis warunkuje tu terapię poprzez wywiedzenie z dzieciństwa baśniowego, mitycznego porządku świata", eadem, op. cit., s. 218.

${ }^{26}$ B. Przymuszała, Smugi Zagłady. Emocjonalne i konwencjonalne aspekty tekstów ofiar i ich dzieci, Poznań 2016, s. 250. 
Lis $\mathrm{w}$ prozie Tulli - mimo że nadaje mu się status przyjaciela - nie przestaje być istotą odrębną, drapieżnikiem ${ }^{27}$. Nie jest udomowionym zwierzęciem, jak kot i pies, które są zależne od pana i które odpłacają mu w mniejszym (kot) lub większym (pies) stopniu wiernością i miłością. Nie jest też istotą niewinną — poluje na kury, co oznacza, że bez skrupułów zadaje śmierć. Mówi się o tym jednak w książce Tulli dość oględnie, nie tak jak w makabrycznej bajce Jana Lemańskiego, w której lis odgryza gęsi głowę i cały we krwi „chrupie przyjacielskie zwłoki”"28.

Przyjaciel bohaterki Szumu musi po prostu walczyć o przetrwanie, w czym przypomina tytułową postać z powieści młodzieżowej Michel-Aimégo Baudouy Władca stromych wzgórz. Lis, zwany Grubasem (minimalnie i dyskretnie antropomorfizowany, jeśli porównać tę kreację z kreacjami znanymi z bajek), został w niej ukazany ze zrozumieniem, respektem i sympatią, choć poluje nie tylko na leśną zwierzynę, ale też wyjada drób z okolicznych gospodarstw i zręcznie wymyka się parobkom i myśliwym ${ }^{29}$.

Dzięki lisowi dziewczynka zaczyna rozumieć, że nie musi być tylko niewinną ofiarą. Kiedy nieprzyjazny świat narzuca swoje twarde reguły, trzeba szukać sposobów na przetrwanie. Bohaterka stosuje strategie przetrwania na swoją miarę — kłamie bez zmrużenia powiek, jeździ autobusem bez biletu, pozwala sobie na ataki furii, wie, że nie jest odpowiedzialna za całe zło i niesprawiedliwość świata.

\section{Farbowane lisy}

Bycie innym i wykluczonym może mieć wiele wymiarów. Bohaterka Wtoskich szpilek doświadcza także upokorzeń jako córka Żydówki i Włocha, który — $\mathrm{z}$ racji wyglądu i akcentu — też podejrzewany jest o żydowskie pochodzenie. Kulminacja pogromowej atmosfery w Polsce przypada na wiosnę 1968 roku, w czasie protestów studenckich i antysemickiej oraz antyinteligenckiej nagonki prowadzonej przez władze. Tulli nie podaje roku, ale opis ulicznych wydarzeń (interwencje uzbrojonej w pałki milicji, pogoń za demonstrantami oraz wiece w zakładach pracy) przy wyraźnym wskazaniu, że wszystko odbywa się w Dniu Kobiet, to wystarczająca wskazówka. Właśnie 8 marca 1968 roku na terenie Uniwersytetu Warszawskiego miała miejsce słynna manifestacja studentów, która zapoczątkowała i zainspirowała podobne wystąpienia na terenie całego kraju ${ }^{30}$.

Wtedy też dziewczynka dowiaduje się, że należy do grona „farbowanych lisów", a więc ludzi, którzy nie są polskimi patriotami, ponieważ w ogóle nie

27 Ibidem, s. 249.

28 J. Lemański, Lis i Gęś, [w:] idem, Wybór bajek, Warszawa 1956, s. 45.

${ }^{29}$ M.A. Baudouy, Władca stromych wzgórz, przeł. O. Nowakowska, Warszawa 1975, s. 114, $134-144$.

30 J. Eisler, Polski rok 1968, Warszawa 2006, s. 224-276. 
są prawdziwymi Polakami ${ }^{31}$. Co gorsza - przypomina Tulli antysemickie klisze Marca '68 - maskują się i jedzą nie swój chleb. „Farbowane lisy” oznacza w tym kontekście tyle co: oszuści, niewdzięcznicy, zdrajcy, wrogowie. Obraźliwe określenie sygnalizuje, że „prawdziwi Polacy” nie dają się jednak zwieść i skrupulatnie prowadzą, jak pisze Beata Przymuszała, „ewidencję obcych”32. Może także odsyłać do sposobu ukazywania w hitlerowskiej propagandzie Żydów jako szkodników, traktowania ich jako zwierzyny łownej (,Judenjagd”) czy też budzić skojarzenia z innym użyciem maski zwierzęcej w słynnym komiksie Arta Spiegelmana Maus, w którym prześladowani zostali ukazani jako myszy ${ }^{33}$.

W propagandzie peerelowskiej okresu Marca '68 osoby żydowskiego pochodzenia władza zwykła wówczas nazywać „syjonistami”, oskarżać o sprzyjanie obcemu państwu (Izraelowi) i nakłaniać do opuszczenia Polski ${ }^{34}$. Żydowski aspekt tożsamości dziewczynki rzuca światło na źródła jej rodzinnego dramatu. Bohaterka Włoskich szpilek i Szumu jako dziecko osoby ocalonej z Zagłady wykazuje objawy psychicznego urazu charakterystyczne dla przedstawicieli „drugiego pokolenia" ${ }^{35}$. Jej matka straciła w Holocauście prawie całą rodzinę. Kiedy zaraz po wojnie próbowała mówić o swoich doświadczeniach, inni ocaleni nie chcieli dłużej słuchać o przeszłości, więc zamilkła, zamykając w sobie pamięć i cierpienie. Najbardziej obawiała się, jak zgaduje córka, wspomnienia chwili, gdy transport z jej rodziną przybył z getta w Łodzi do Oświęcimia. Wszyscy zginęli w komorach gazowych oprócz niej i jej młodszej siostry Haliny:

Moja matka przez długie lata omijała to wspomnienie, być może grunt pamięci zapadłby się pod jego ciężarem jak spróchniała deska. (WS, 69)

Wojenna tragedia ujawnia się we Włoskich szpilkach za sprawą choroby matki, która cierpiąc na alzheimera, nie potrafi dłużej kontrolować swoich wspomnień. W Szumie wątek Zagłady powraca, choć na pierwszy plan wysuwa się tu postać Haliny, młodszej siostry mamy. Niedzielne rodzinne spotkania przy szarlotce oznaczają dla dziewczynki, także później, gdy jest już dorosłą kobietą, pełne

${ }^{31}$ A. Szczepan, Rozrachunki z postpamięcia, [w:] Od pamięci biodziedzicznej do postpamięci, red. T. Szostek, R. Nycz, R. Sendyka, Warszawa 2013, s. 323-324. Warto odnotować, że postać Lisa w kontekście antysemickich oskarżeń wykorzystał w przewrotny sposób Sławomir Mrożek w humoresce Podejrzenie ze zbioru Małe prozy (Kraków 1990, s. 93).

32 B. Przymuszała, Smugi Zagłady..., s. 245.

33 Ibidem, s. 244-245.

${ }^{34}$ Zob. Przemówienie I sekretarza KC PZPR, tow. Władystawa Gomułki, na spotkaniu z aktywem warszawskim w dniu 19 marca 1968 r, „Nowe Drogi” 1968, nr 4, s. 3-24.

${ }^{35}$ Zob. A. Szczepan, op. cit.; A. Mach, „Na początku była wojna”. Postpamięć w utworach Evy Hoffman, Bożeny Keff, Ewy Kuryluk i Agaty Tuszyńskiej, „Literaturoznawstwo” 2014-2015, nr 8-9, s. 139-175; S. Karolak, Utwory o matkach i córkach. Kobiece narracje postmemorialne, „Politeja” 2015, nr 35 (3), s. 171-187; B. Przymuszała, Między „Włoskimi szpilkami” a „Szumem” Magdaleny Tulli - wokót problemu ofiary. Re-lektura emocji, [w:] eadem, Smugi Zagłady..., s. $235-284$. 
upokorzeń konfrontacje z matką i ciotką, dwiema najbliższymi osobami, które zawsze sprzymierzają się przeciw niej.

\section{Sąd}

Postać lisa powraca w końcowych partiach Szumu. Tym razem jednak wciela się on w publiczną rolę — przewodniczy rozprawie sądowej „Sądu Najniższego”. Jest to sąd nad zmarłymi i żyjącymi, sąd nad przeszłością, ale z otwarciem na przyszłość, wreszcie sąd, którego celem nie jest zmierzenie win i wyznaczenie kar, ale... przebaczenie:

— Zebraliśmy się dzisiaj wszyscy w Sądzie Najniższym po to, żeby... — zaczął lis i urwał.

—Żeby się osądzić! — podpowiedział esesman.

—Żeby sobie wybaczyć - dokończył lis i machnął kitą, żeby mu nie przeszkadzali. (Sz, 165)

Odrealniona, oniryczna scena sądu następuje zaraz po zdarzeniu, którego opis ma jak najbardziej realistyczną motywację - mianowicie po sprawie rozwodowej bohaterki. Ten trudny, przełomowy moment sprzyja życiowym podsumowaniom i rozliczeniom. W rozprawie prowadzonej przez lisa w podziemiach prawdziwego sądu przewija się korowód postaci, które odegrały istotną rolę w życiu bohaterki, ale brakuje tych najważniejszych - matki i ciotki. Czy to status ocalonych z Zagłady zwolnił je od odpowiedzialności? Chodzi nie tylko o to obie postanowiły „trzymać gardę wysoko" i wybrały ignorowanie holocaustowej przeszłości i jej skutków, to zaś, co przemilczane, po prostu nie istnieje (Sz, 170). Zaprzeczały w ten sposób konsekwentnie sugestii, że dziewczynka dziedziczy ciężar ich doświadczeń, że stała się ofiarą ich traumy.

Lokalność i prywatność sądowej rozprawy, jaką kreuje Tulli, dobrze uwypukla zestawienie Szumu z powieścią Andrzeja Barta Fabryka muchołapek ${ }^{36}$. Treścią Fabryki, która dotyka problemu „niechlubnej, żydowskiej przeszłości”37, jest w całości sąd nad historyczną, kontrowersyjną postacią - Chaimem Rumkowskim. Rozprawa toczy się, podobnie jak u Tulli, w wyimaginowanej rzeczywistości, wiele lat po wojnie. Jednak sędzia obdarzony jest boskimi atrybutami: wszechwiedzą, autorytetem, sugestią możliwości wpływania na losy świata i mocą, której niekiedy używa wobec świadków ${ }^{38}$. Rozmach procesu dobrze oddaje dobór występujących przed sądem postaci. Są wśród nich słynne historyczne figury, nie zawsze nawet bezpośrednio związane z łódzkim gettem: Dawid Sierakowiak,

${ }^{36}$ A. Bart, Fabryka muchołapek, Warszawa 2008.

37 M. Cuber, All exclusive. Retrorynek w „Fabryce mucholapek” $i$,, Rewersie” Andrzeja Barta, „Śląskie Studia Polonistyczne” 2012, nr 2, s. 244.

38 Tej wizji można przeciwstawić koncept sądu, jaki pojawia się w powieści Niekochana Arnošta Lustiga. W opowieści o młodej prostytuującej się Żydówce w getcie w Terezinie stary rabin oskarża, sądzi i skazuje Boga na to, żeby był człowiekiem i trafił do obozu. Zob. A. Lustig, Niekochana ( z dziennika siedemnastoletniej Perly Sch.), przeł. J. Stachowski, Kraków 2004, s. 127-129. 
doktor Korczak, Hannah Arendt, a nawet kierownik niemieckiej administracji getta Hans Biebow.

Co ciekawe, surowy osąd, nawet nie tyle czynów, ile postawy i charakteru Rumkowskiego, nie wyklucza go ze społeczności ofiar. Jednak zawstydza i odmienia Prezesa, czego sygnałem jest finalna scena wyjazdu, gdy starzec pomaga nieść żonie walizki. Rozprawa okazuje się formą teatralizacji minionego ${ }^{39}$, poniekąd seansem z pogranicza Dziadów (Mickiewicza) i psychoanalizy, służy przywołaniu i przepracowaniu dojmującej przeszłości ${ }^{40}$.

Interesująco w tym kontekście prezentuje się w Fabryce muchołapek i Szumie wątek rozliczeń z bezpośrednimi sprawcami wojennego zła $-\mathrm{z}$ Niemcami. $\mathrm{W}$ powieści Barta pojawiają się dwie kontrastowo zestawione figury — wspomniany już Biebow oraz szeregowy żołnierz Johann Krüger. O ile pierwszy okazuje się zatwardziałym faszystą, pogardliwym i nadal ogarniętym nienawiścią do Żydów, o tyle drugi wykazuje autentyczną skruchę, choć jego winy są nieporównanie mniejsze. Dlatego na pierwszego spada gniew sędziego, który kolejny raz wychodzi ze swej roli, gdy drugi spotyka się z życzliwością, a nawet obietnicą złagodzenia wyrzutów sumienia.

W Szumie narratorka już wcześniej w przewrotny sposób sygnalizowała swoje relacje z Niemcami, niemal prowokacyjnie oświadczając: „Wehrmacht porzucił Hitlera i przeszedł na moją stronę". To, co w Polsce Ludowej lat pięćdziesiątych czy sześćdziesiątych byłoby poczytane za zdradę, wiele lat po wojnie nabrało znamion zwyczajności, wyglądało na formę uregulowania międzyludzkich stosunków: „będę jeść z nimi zupę i drugie i będę z nimi rozmawiać o przeszłości, i [...] słuchając o stryjach, którzy zostali na Wschodzie, zasypani śniegiem, zaniedbam za każdym razem przypomnieć z naciskiem, ile przez nich wycierpiał nasz kraj” (Sz, 77).

Jednak w scenie sądu okupantów nie reprezentuje żołnierz Wehrmachtu, ale dwuznaczna postać esesmana, który podczas ostatniego marszu śmierci karmił więźniów cukrem ze swoich prywatnych zapasów i zapewne ocalił im życie. Po wyzwoleniu obozu przez Amerykanów został zastrzelony przez jednego z obcych więźniów, a matka bohaterki, która dzięki niemu przeżyła morderczy marsz, nie stanęła w jego obronie. Nie wiemy o wcześniejszych winach (zbrodniach?) tego człowieka, jednak sam fakt bycia esesmanem wydaje się dostatecznie obciążający.

Niemiec jest teraz związany, ale traktowany dobrze, dostaje nawet od bohaterki kawałek czekolady. Esesman jest pogodzony ze swoim losem. Zebrani karmią go, bo nie są okrutni, ale nie zamierzają rozwiązać, ponieważ czują się odpowiedzialni za przyszłość. W tym symbolicznym obrazie zawiera się coś w rodzaju programowej postawy powojennych pokoleń wobec niemieckich sprawców i idei nazizmu, która splotła się historycznie z niemieckim państwem. $Z$ jednej strony więc, zwłaszcza kiedy mowa o Wehrmachcie, pojawia się potrzeba normalizacji

${ }^{39}$ M. Cuber, All exclusive..., s. 246-247.

${ }^{40}$ M. Heydel, op. cit. 
stosunków z Niemcami, próba zrozumienia i akceptacji ich cierpień, z drugiej sposób postrzegania formacji SS naznaczają kategorie uwięzienia i kary, pamięć zaś i odpowiedzialność to bezpieczniki chroniące świat przed recydywą Zagłady.

\section{Podsumowanie}

Wysłowienie traumatycznych doświadczeń przeszłości w autobiograficznych powieściach Magdaleny Tulli, Włoskie szpilki i Szum, ma charakter nie tylko udanego literackiego przedsięwzięcia, lecz także jest formą dopełnienia wielkiej psychicznej pracy autorki nad przezwyciężeniem skutków nieszczęśliwego dzieciństwa. Fakt odrzucenia dziewczynki przez matkę oraz liczne przykłady opresyjności zewnętrznego świata przełożyły się na życiowe niepowodzenia i dysfunkcje emocjonalne bohaterki, co Tulli sugestywnie zamyka w poruszających, melancholijno-depresyjnych trybach narracji.

Ważnym wątkiem, wzbogacającym psychologiczną i socjologiczną wiwisekcję egzystencji rodziny o włosko-żydowskich korzeniach, jest kwestia Holokaustu oraz powojennego antysemityzmu w Polsce. Narratorka obu powieści dociera do źródeł dewastującego doświadczenia Zagłady, które stało się udziałem matki i jej młodszej siostry. W tym kontekście przejmująca skarga na nieszczęśliwe dzieciństwo, łagodzona kreacją fikcyjnego przyjaciela — lisa, przyjmuje równolegle postać trudnego przebaczenia, obejmującego najbliższe osoby, czyli krzywdzicielki, które same stały się ofiarami.

\section{Bibliografia}

Andrzejewski J., Złoty lis, [w:] idem, ,,Niby gaj” i inne opowiadania, Warszawa 1967.

Bart A., Fabryka muchołapek, Warszawa 2008.

Barthes R., La chambre claire. Note sur la photographie, Paris 1980.

Baudouy M.A., Władca stromych wzgórz, przeł. O. Nowakowska,Warszawa 1975.

Cuber M., All exclusive. Retrorynek w „Fabryce mucholapek” $i$ „,Rewersie” Andrzeja Barta, „Śląskie Studia Polonistyczne" 2012, nr 2, s. 241-255.

Cuber M., Metonimie Zagłady. O polskiej prozie lat 1987-2012, Katowice 2013.

Darska B., Wina i przebaczenie, „Nowa Dekada” 19.12.2014, http://nowadekada-online.pl/recenzuje-bernadetta-darska-z-magdalena-tulli-rozmawia-sabina-misiarz-filipek/ [dostęp: 10.10.2017].

Dzika-Jurek K., Problem ciężaru. Melancholia w twórczości Magdaleny Tulli, Katowice 2014, http://www.sbc.org.pl/Content/139135/doktorat3519.pdf [dostęp: 21.03.2018].

Eisler J., Polski rok 1968, Warszawa 2006.

Freud Z., Przypominanie, powtarzanie i przepracowanie, [w:] Zygmunt Freud: czlowiek i dzieło, przeł. B. Kocowska et al., red. K. Pospiszyl, Wrocław 1991.

Gomułka W., Przemówienie I sekretarza KC PZPR, tow. Władysława Gomulki, na spotkaniu z aktywem warszawskim w dniu 19 marca 1968 r., „Nowe Drogi” 1968, nr 4, s. 3-24.

Gondowicz J., Lust zu fabulieren, „Nowe Książki” 2003, nr 6, s. 59.

Heydel M., Byliśmy nieprzyjaciótmi, „dwutygodnik.com” 2014, nr 143, http://www.dwutygodnik. com/artykul/5479-bylismy-nieprzyjaciolmi.html [dostęp: 23.01.2017]. 
Jaka piękna iluzja. Magdalena Tulli w rozmowie z Justyną Dąbrowską, Kraków 2017.

Karolak S., Utwory o matkach i córkach. Kobiece narracje postmemorialne, „Politeja” 2015, nr 35 (3), s. 171-87.

LaCapra D., Historia w okresie przejściowym, przeł. K. Bojarska, Kraków 2009.

Lemański J., Lis i Gęś, [w:] idem, Wybór bajek, Warszawa 1956.

Lustig A., Niekochana (z dziennika siedemnastoletniej Perly Sch.), przeł. J. Stachowski, Kraków 2004.

Łupak S., Dziewczynka, esesman i lis. Nowa książka Magdaleny Tulli, „Newsweek” 13.10.2014, http://www.newsweek.pl/kultura/szum-nowa-powiesc-magdaleny-tulii-newsweek-pl,artykuly, 348135,1.html [dostęp: 12.02.2018].

Mach A., , Na początku była wojna”. Postpamięć w utworach Evy Hoffman, Bożeny Keff, Ewy Kuryluk i Agaty Tuszyńskiej, „Literaturoznawstwo” 2014-2015, nr 8-9, s. 139-75.

Mrożek S., Podejrzenie, [w:] idem, Mate prozy, Kraków 1990.

Nowacki D., ,, Szum ” Magdaleny Tulli. Powieść nie do przecenienia, „Gazeta Wyborcza” 30.09.2014, http://wyborcza.pl/1,75410,16725324,_Szum_Magdaleny_Tulli_Powiesc_nie_do_przecenienia_html [dostęp: 28.03.2018].

Nowacki D., W rekwizytorni, „Kresy” 1998, nr 36, s. 60-62.

Nowacki D., Wyzwolenie, ukojenie, „Tygodnik Powszechny” 2012, nr 43, dodatek „Angelus”, s. 46.

Orska J., Grubymi nićmi szyte, „Arkusz” 1999, nr 3, s. 7.

Orski M., W jatowych piaskach historyjek, „Odra” 2003, nr 12, s. 101-102.

Przymuszała B., Między „Włoskimi szpilkami” a „,Szumem” Magdaleny Tulli — wokót problemu ofiary. Re-lektura emocji, [w:] eadem, Smugi Zagłady. Emocjonalne i konwencjonalne aspekty tekstów ofiar i ich dzieci, Poznań 2016, s. 235-84.

Rąbkowska E., Potrzeba początku: kategoria dzieciństwa w polskiej wspótczesnej prozie wspomnieniowej, Warszawa 2015.

Rusek M., Niewystuchany krzyk, [w:] Światy dzieciństwa. Infantylizacje w literaturze i kulturze, red. M. Chrobak, K. Wądolny-Tatar, Kraków 2016.

Sobolewski T., Nie ma zmyślonych opowieści, „Gazeta Wyborcza” 15-16.09.2012, http://wyborcza. pl/1,75410,12487543,Nike_2012_Magdalena_Tulli_Nie_ma_zmyslonych_opowiesci.html [dostęp: 11.12.2017].

Szczepan A., Rozrachunki z postpamięcia, [w:] Od pamięci biodziedzicznej do postpamięci, red. T. Szostek, R. Sendyka, R. Nycz, Warszawa 2013, s. 323-24.

Tulli M. [jako Marek Nocny], Kontroler snów, Warszawa 2007.

Tulli M., Skaza, Warszawa 2006.

Tulli M., Sny i kamienie, Warszawa 1995.

Tulli M., Szum, Kraków 2014.

Tulli M., Tryby, Warszawa 2003.

Tulli M., W czerwieni, Warszawa 1998.

Tulli M., Włoskie szpilki, Warszawa 2011.

W utartych torach nie miałam szczęścia się znaleźć, z Magdaleną Tulli rozmawia Sabina Misiarz-Filipek, „Nowa Dekada” 19.12.2014, http://nowadekada-online.pl/recenzuje-bernadetta-darska-z-magdalena-tulli-rozmawia-sabina-misiarz-filipek/ [dostęp: 19.10.2017].

Wiegandt E., ,,To” Magdaleny Tulli, „Poznańskie Studia Polonistyczne. Seria Literacka” 2013, nr 22 (42), s. 143-56.

Zaleski M., Formy pamięci. O przedstawianiu przeszłości w polskiej literaturze współczesnej, Warszawa 1996.

Zaleski M., Złowróżbna łatwość stwarzania świata, „Gazeta Wyborcza” 2006, nr 26, dodatek „Kultura", s. 13.

Zbuntowana, z Magdaleną Tulli rozmawia Dorota Wodecka, „Gazeta Wyborcza” 2014, nr 225, s. 12 14, http://wyborcza.pl/magazyn/1,124059,16711994,Zbuntowana rozmowa_z_Magdalena_Tulli.html [dostęp: 14.09.2017]. 


\section{The self-portrait with a fox. The past to overcome in Magdalena Tulli's autobiographical prose}

Summary

The author focuses on the creation of the children's hero from autobiographical novels by Magdalena Tulli: Włoskie szpilki (2011) and Szum (2014). The expressing of traumatic experience from the past in Tulli's works takes not only the form of a successful artistic endeavour, but is also a kind of self-care. Waligóra argues that the fact of rejecting a girl by her mother and numerous examples of oppressiveness of the outside world result in life failures, the heroine's emotional dysfunction and melancholic-depressive nature of memories.

The psychological and sociological vivisection of the existence of a family of Jewish (mother) and Italian (father) origin is enriched by the Holocaust and postwar anti-Semitic topics. The female narrator of both novels explores the sources of devastating experience of Shoah that became a painful part of her mother's and aunt's biography. The moving complaint about an unhappy childhood, tempered by the creation of a fictional friend - a fox, takes the form of a difficult forgiveness in parallel, the forgiveness including the closest people: the wrongdoers who have become victims themselves.

Keywords: Tulli, postmemory, trauma, childhood, Holocaust, literature, autobiography 